\title{
13. MINERALOGIC STUDIES OF SEDIMENTS FROM THE NORWEGIAN-GREENLAND SEA (SITES 336, 343, 344, 345, AND 348)
}

\author{
Edward A. Perry, Jr., Stephen J. Grady, and William M. Kelly, \\ Department of Geology. University of Massachusetts, Amherst, Massachusetts
}

\section{INTRODUCTION}

This sludy is part of a collaborative effort into the geochemistry of sediment-pore water interactions in deep-sea sediments. Gieskes et al. (this volume) present the results of pore water chemistry and oxygen isotope studies. Our mineralogic studies are aimed at the clarification of possible mechanisms which can control the trends observed in the pore water compositions. We have primarily focused on the clay mineralogy of the $<1 \mu \mathrm{m}$ size fraction, but have also examined the mineralogy of the coarser size fractions and bulk sediment samples.

\section{Samples Studied and Methods}

The sites selected for study were those which exhibited the larger chemical gradients in their pore water composition: Site 336 (Iceland-Faeroe Ridge), Site 343 (Lofoten Basin), Site 344 (Knipovich Ridge), Site 345 (Mohns Ridge), and Site 348 (Icelandic Plateau). The samples examined were the same sediment plugs squeezed onboard ship for the pore water studies. The exact centimeter interval of the core-sections can therefore be obtained by referring to the report of Gieskes et al. (this volume).

The sediments were ultrasonically disaggregated and washed several times in distilled water until flocculation no longer occurred. The resulting suspensions were then repeatedly size cut by centrifugal sedimentation into the $<1 \mu \mathrm{m}$ and $>1 \mu \mathrm{m}$ size fractions. An oriented $<1 \mu \mathrm{m}$ sample was prepared by evaporative setting onto a glass slide at room temperature. The $>1 \mu \mathrm{m}$ fraction and bulk sediment samples were gently ground in acetone, slurried onto a glass slide, and examined by $X$-ray diffraction (XRD). For several samples, the $>62$ $\mu \mathrm{m}$ fraction was separated by wet sieving and examined microscopically.

The clay mineralogy was determined by XRD studies of air-dried and ethylene glycol solvated samples. Unfortunately we were unaware until the end of our laboratory work that other XRD studies were being carried out by the Phillips and British Petroleum laboratories. Our clay mineral studies were of the $<1$ $\mu \mathrm{m}$ fraction, while they examined the $<2 \mu \mathrm{m}$ and $<5$ $\mu \mathrm{m}$ size fractions, respectively. It should also be noted that the $<5 \mu \mathrm{m}$ fraction was separated after grinding, and the mineralogy reported is probably not representative of that size range in the unground sediment.

In order to allow that the trends in our data be compared to those of the other studies, we have calculated mineral abundances in the same manner as was done by the petroleum laboratories. The clay mineral abun- dances were calculated by the methods of Biscaye (1965), and the proportion of smectite layers in mixedlayer illite/smectite determined by computer simulation techniques of Reynolds and Hower (1970).

These estimates are notoriously inaccurate and are useful for only relative comparisons. This is especially true for the mixed-layer illite/smectites (hereafter simply referred to as illite/smectite) because the intensity of the $17 \AA$ XRD peak varies as a function of the proportion of the smectite layers. The situation is further complicated by the fact that the illite/smectites in many of these sediments are a heterogeneous mixture because there is a significant range in their proportion of smectite layers. The computer simulated XRD patterns of Reynolds and Hower (1970) cannot be applied to such a heterogeneous mixture, and it is meaningless to report the "percent of smectite layers" for these illite/smectites.

Some samples, however, do have illite/smectites which are fairly homogeneous in their proportion of smectite layers. These clays are nearly pure smectites and have presumably formed by the in situ alteration of volcanics (Perry et al., in press). Clays which have a heterogeneous mixture of illite/smectites probably have a mixed provenance which includes terrigenous and submarine sources.

\section{RESULTS AND DISCUSSION}

The clay mineral abundances are reported in Table 1. If the $3.5 \AA$ XRD peak could not be resolved for kaolinite and chlorite (Biscaye, 1965), the abundance is simply reported as percent kaolinite/chlorite. Quartz and feldspar are ubiquitous in the coarse fraction and are therefore not reported. If other mineral phases were confirmed by the presence of two or more XRD peaks, their occurrence is noted in Table 1. Figure 1 summarizes the clay mineral data for each of the five sites examined. The percent "smectite" (illite/smectite) is divided by the sum of the percent illite plus kaolinite plus chlorite, as these phases are mostly detrital. Some of the smectite is certainly detrital as well, but higher abundances of smectite can generally be expected to correlate with increased altered volcanic contributions. Whenever possible, attempts are made to correlate our observed changes in mineralogy with suspected tectonic events and the trends observed in the pore water chemistry (Gieskes et al., this volume).

\section{Site 336}

This site was drilled on the northern flank of the Iceland-Faeroe Ridge, and three sedimentary units have been described in the initial core descriptions. 
TABLE 1

Clay Mineral Abundances in the $<1 \mu \mathrm{m}$ Fraction

\begin{tabular}{|c|c|c|c|c|c|c|c|c|c|}
\hline $\begin{array}{l}\text { Core- } \\
\text { Section }\end{array}$ & $\begin{array}{l}\text { Depth } \\
(\mathrm{m})\end{array}$ & Age & $\begin{array}{l}\% \\
\mathrm{I} / \mathrm{S}\end{array}$ & $(\%$ Exp) & $\begin{array}{c}\% \\
\text { Illite }\end{array}$ & $\begin{array}{c}\% \\
\text { Kaol + } \\
\text { Chl. }\end{array}$ & $\begin{array}{c}\% \\
\text { Kaol. }\end{array}$ & $\begin{array}{c}\% \\
\text { Chl. }\end{array}$ & $\begin{array}{l}\text { Coarse Fraction } \\
\text { Mineralogy }\end{array}$ \\
\hline \multicolumn{10}{|l|}{ Site 336} \\
\hline $1-4$ & 5 & Glacial & 32 & (Hetero) & 39 & - & 16 & 13 & \\
\hline $5-5$ & 42 & Glacial & 50 & (Hetero) & 32 & - & 10 & 8 & \\
\hline $8-4$ & 69 & Plio. & 51 & (Hetero) & 31 & - & 8 & 10 & \\
\hline $11-4$ & 117 & Plio. & 13 & (Hetero) & 57 & - & 0 & 29 & \\
\hline $16-4$ & 183 & Mid. Olig. & 55 & (Hetero) & 36 & 5 & - & - & Glauconite, pyrite \\
\hline $18-4$ & 193 & $?$ & 57 & (Hetero) & 33 & 10 & - & - & Pyrite \\
\hline $22-5$ & 242 & Eoc. or Olig. & 37 & (Hetero) & 50 & 13 & - & - & Phillipsite \\
\hline $27-5$ & 289 & Late Eoc. & 43 & (Hetero) & 37 & 21 & - & - & Phillipsite \\
\hline $30-4$ & 335 & Late Eoc. & 59 & (75) & 26 & 15 & - & - & Phillipsite, pyrite \\
\hline $33-5$ & 394 & Mid. or late Eoc. & 67 & (75) & 18 & 15 & - & - & Phillipsite, pyrite \\
\hline $35-3$ & 429 & Mid. or late Eoc. & 78 & (75) & 12 & 9 & - & - & Phillipsite, pyrite \\
\hline $39-3$ & 476 & $?$ & 100 & $(100)$ & 0 & 0 & - & - & $\begin{array}{l}\text { Hematite, no other } \\
\text { phases present }\end{array}$ \\
\hline
\end{tabular}

Site 343

$\begin{array}{lll}1-1 & 1.5 & \text { Glacial } \\ 3-4 & 56 & \text { Glacial } \\ 4-2 & 101 & \text { Glacial } \\ 5-5 & 153 & \text { Mid. Eoc. } \\ 7-2 & 205.5 & \text { Mid. Eoc. } \\ 15-2 & 272 & \text { Early Eoc. }\end{array}$

$\begin{array}{rlrrrr}8 & \text { (Hetero) } & 55 & - & 22 & 15 \\ 29 & \text { (Hetero) } & 55 & - & 8 & 9 \\ 8 & \text { (Hetero) } & 68 & - & 12 & 12 \\ 73 & \text { (Hetero) } & 20 & 6 & - & - \\ 80 & (100) & 8 & - & 6 & 6 \\ 0 & - & 62 & - & 0 & 38\end{array}$

Gypsum

Expanding chlorite

Site 344

\begin{tabular}{lrl}
$2-1$ & \multicolumn{3}{c}{3} & Glacial \\
$6-4$ & 45.5 & Glacial \\
$11-1$ & 88.5 & Glacial \\
$15-5$ & 132.5 & Plio. \\
$21-1$ & 183.5 & Plio. \\
$27-2$ & 242 & Plio. \\
$31-1$ & 319.5 & Plio. or Mio. \\
$33-1$ & 373.5 & Plio. or Mio.
\end{tabular}

$\begin{array}{rlrlrr}23 & \text { (Hetero) } & 46 & - & 16 & 15 \\ 23 & \text { (Hetero) } & 52 & - & 13 & 12 \\ 25 & \text { (Hetero) } & 54 & - & 11 & 10 \\ 37 & \text { (Hetero) } & 41 & - & 12 & 10 \\ 57 & (75) & 30 & - & 7 & 6 \\ 38 & (75) & 40 & - & 11 & 11 \\ 20 & \text { (Hetero) } & 45 & - & 17 & 18 \\ 0 & & 58 & - & 0 & 42\end{array}$

\section{Site 345}

$\begin{array}{lcl}1-1 & 1.5 & \text { Glacial } \\ 4-1 & 28.5 & \text { Glacial } \\ 7-1 & 76 & \text { Early Mio. } \\ 10-4 & 137.5 & \text { Mio.-late Olig. } \\ 14-4 & 249 & \text { Olig. } \\ 16-5 & 347 & \text { Olig. } \\ 19-4 & 451 & \text { Olig. } \\ 20-2 & 486 & \text { Olig. } \\ 21-4 & 527 & \text { Olig. } \\ 23-5 & 604.5 & \text { Late Eoc.(?) }\end{array}$

$\begin{array}{rlrrrr}6 & \text { (Hetero) } & 76 & - & 9 & 9 \\ 11 & \text { (Hetero) } & 63 & - & 14 & 12 \\ 52 & \text { (Hetero) } & 30 & - & 12 & 15 \\ 67 & (75) & 21 & - & 8 & 4 \\ 62 & \text { (Hetero) } & 26 & - & 8 & 5 \\ 33 & \text { (Hetero) } & 42 & - & 16 & 9 \\ 88 & (100) & 8 & 4 & - & - \\ 59 & (75) & 29 & - & 8 & 4 \\ 68 & (75) & 27 & 5 & - & - \\ 69 & (75) & 27 & 2 & - & -\end{array}$

Pyrite

Site 348

\begin{tabular}{lllllllrrr}
$1-4$ & 6 & Glacial & 25 & (Hetero) & 54 & - & 9 & 12 & \\
$4-2$ & 40.5 & Glacial & 24 & (Hetero) & 27 & - & 13 & 9 & \\
$7-3$ & 80 & Plio. & 30 & (Hetero) & 51 & - & 9 & 9 & \\
$9-2$ & 116.5 & Plio. & 53 & (Hetero) & 31 & - & 9 & 7 & \\
$12-5$ & 168.5 & Late Mio. & 56 & (Hetero) & 29 & 15 & - & - & \\
$16-5$ & 235 & Mid. Mio. & 44 & (Hetero) & 41 & 15 & - & - & \\
$20-5$ & 282.5 & Early Mio. & 85 & $(80)$ & 11 & 4 & - & - & Clinoptilolite(?) \\
$24-5$ & 349 & Early Mio. & 65 & $(75)$ & 22 & 12 & - & - & \\
$29-5$ & 492 & Olig. & 56 & $(75)$ & 27 & - & 12 & 6 & \\
$32-2$ & 525 & Olig. & 33 & $(75)$ & 38 & 30 & - & - & Analcime \\
\hline
\end{tabular}

Note: $(\% \mathrm{I} / \mathrm{S})=$ mixed layer illite/smectite, $(\% \mathrm{kaol} .+$ chl. $)=$ chlorite and/or kaolinite when the $3.5 \AA$ XRD peak is not resolved. Coarse fraction mineralogy refers to phases identified by more than 1 XRD peak in addition to quartz and feldspar. 


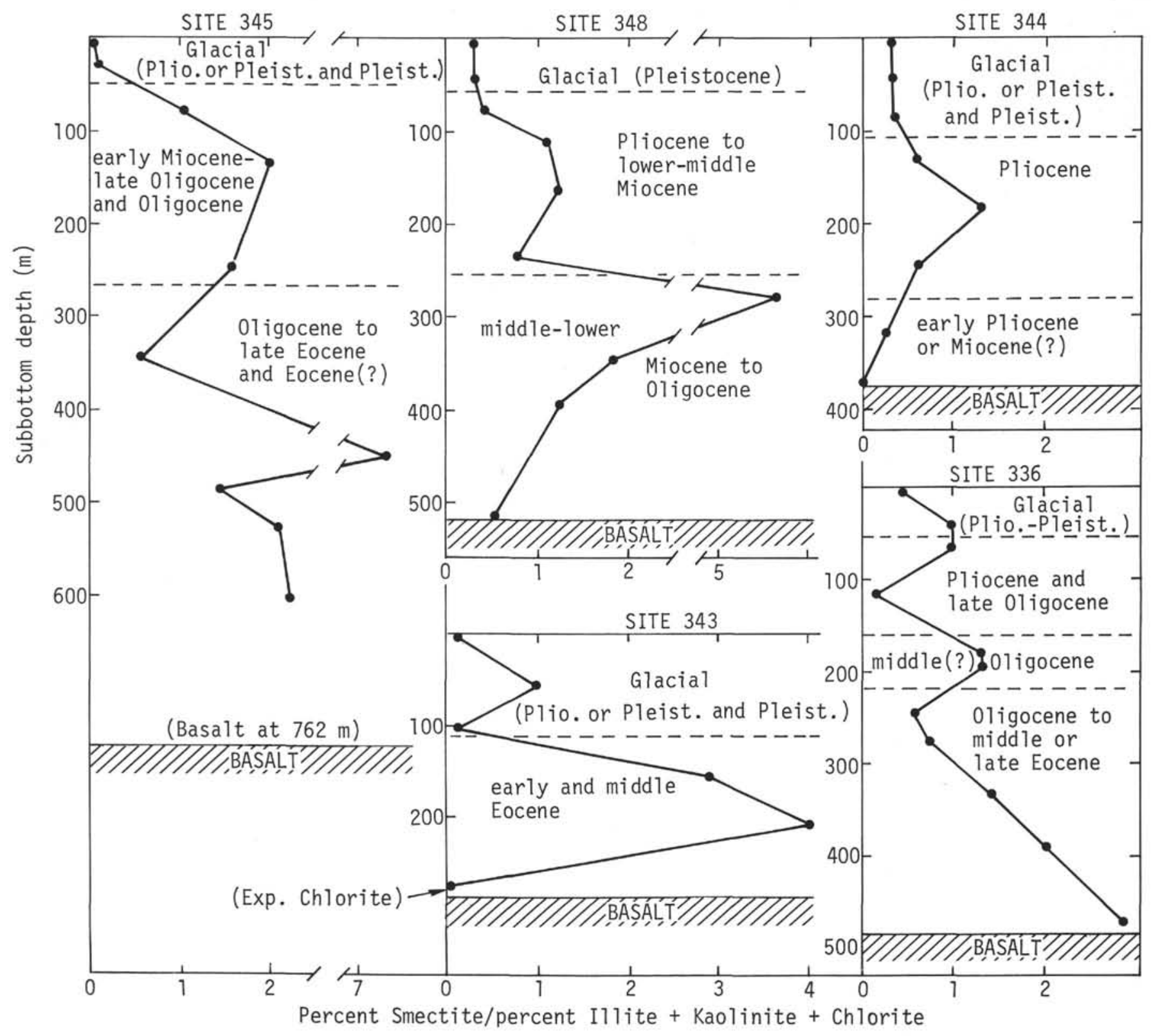

Figure 1. The relationships between $\frac{\% \text { illite/smectite }}{\%(\text { illite }+ \text { chlorite }+ \text { kaolinite) }}$ and subbottom depth for Sites 336, 343, 344, 345 and

348. Higher illite/smectite abundances generally indicate an increased altered volcanic contribution.

Unit $1(0-168.5 \mathrm{~m})$ is "Glacial" to late Oligocene in age, and has a variable clay mineral composition, but generally low amounts of heterogeneous illite/smectite. There is significantly more plagioclase relative to quartz in the Oligocene compared to the overlying glacial sediments. Unit $2(168.5-463 \mathrm{~m})$ is late Oligocene to middle or late Eocene, but the Oligocene samples are mineralogically distinct from the Eocene sediments (Table 1, Figure 1). Glauconite is abundant in Core 16, Section 4, and no zeolites were detected in either Oligocene sample. The Eocene samples show extensive volcanic contributions as evidenced by a progressive increase in smectite in deeper samples and abundant phillipsite in all except the deepest sample which is from Unit 3. It appears that the Eocene sediments were deposited when there was an active spreading center which extended onto the Norway Basin. The westward shift of the center is reflected by a change in the mineralogy of the overlying Oligocene sediments.

Unit 3 sediments were examined only in Core 39 , Section 3, and it is of uncertain, but probable Eocene age. Pyrite is no longer present (Table 1), and hematite and a pure dioctahedral smectite are the only mineral phases detected in all of the size fractions by XRD. Volcanic pebbles are present, but totally altered to these phases. The alteration most probably represents extensive subaerial weathering prior to submergence of the Iceland-Faeroe Ridge.

The trends in the pore water chemistry (Gieskes et al., this volume) are well correlated with the 
mineralogic changes in the sediments. $\mathrm{Ca}$ and $\mathrm{Sr}$ become progressively enriched in the pore waters, while $\mathrm{Mg}$ exhibits a progressive depletion, but these trends become attenuated in the basal sediments, with the $\mathrm{Sr}$ gradient undergoing a marked reversal in the deepest sample. These trends can be best explained by the postdepositional alteration of the volcanic components in the sediments, especially in the Eocene section. As the volcanics undergo submarine "weathering," both $\mathrm{Ca}$ and $\mathrm{Sr}$ are released to the pore waters, but the formation of smectite as an alteration product retains the volcanic $\mathrm{Mg}$ and extracts additional $\mathrm{Mg}$ from the pore waters (Perry et al., in press). The strong depletion in pore water $\delta \mathrm{O}^{18}\left(-3.5^{\circ} / 00\right)$, which parallels these trends, further substantiates this mechanism (Lawrence et al., 1975).

At other locations, a similar alteration also involves the basement basalts (Lawrence et al., 1975; Perry et al., in press), and the pore water gradients related to this alteration do not become attenuated in the overlying sediments. At Site 336, however, the basalts appear to have already been extensively weathered to smectite plus hematite prior to submergence. Evidently, little $\mathrm{Ca}$ and $\mathrm{Sr}$ remained to be released to pore waters after submergence, and no further smectite formation occurred to remove $\mathrm{Mg}$ from the pore waters. It appears that the subaerial smectite fixed $\mathrm{Sr}$ as an exchange ion, causing a depletion of $\mathrm{Sr}$ below seawater values in the deepest sample (Core 39, Section 3).

The pore water alkalinity and $\mathrm{SiO}_{2}$ values assume low and constant values in the volcanic Eocene section, and the high values of $\mathrm{SiO}_{2}$ in the overlying sediments are due to the solution of biogenic silica. Pore water K exhibits a steady depletion through this Eocene section which correlates with the steady increase in illite/smectite (Figure 1), but is probably also related to the formation of phillipsite. Pore water Mn values continue to increase to the deepest sample which is to be expected because Mn would be retained in an oxidized form during subaerial weathering.

\section{Site 343}

This site was drilled at the foot of V $\phi$ ring Plateau in the Lofoten Basin. The upper 108 meters are "Glacial" (Pliocene or Pleistocene and Pleistocene). No samples were recovered from the 108-146 meter interval, but below 146 meters early and middle Eocene sediments were recovered with a basalt sill (?) intruded at the 253269 meter interval. The "Glacial" sediments are enriched in detrital clays, while the Eocene sediments have abundant illite/smectite, presumably derived from the alteration of volcanics which were more abundant when a spreading center was in close proximity during the Eocene.

The clay mineralogy of Core 15 , Section 2 , which is in a sediment interbed in the basalts, is distinctly different. It is totally illite plus chlorite, but the chlorite is a mixed-layered expanding chlorite with some normal (detrital?) chlorite probably present as well. The expanding layers are brucite deficient, hence causing the anomalously strong $14.5 \AA$ XRD peak. Upon glycolation, the $14.5 \AA$ spacing increases to $15.6 \AA$ due to the repetition of $14 \AA$ (nonexpanding) and $17 \AA$ (expanding) layer spacings. A $31 \AA \AA$ superlattice peak typical of wellordered corrensites could not be detected. The expanding chlorite could have been derived from the underlying altered basalts (higher temperature?), or formed during diagenesis when the sill was intruded. In the latter case, the precursor mineral would have been a $\mathrm{Mg}$-rich smectite which originally formed during a lower temperature alteration of the volcanics.

The pore water $\mathrm{Ca}, \mathrm{Sr}$, and $\mathrm{Mg}$ trends are similar to those observed at Site 336, but appear to continue into the basalts which have undergone an alteration involving oceanic pore waters. The abundance of chlorite would seem to indicate submarine alteration, whereas the subaerially weathered basalts found at Site 336 contained no chlorite. The gradients steepen in the Eocene sediments, and the alteration of sedimentary volcanic material also contributes to the gradients as well as the alteration of the underlying basalts.

The uppermost Eocene sample (Core 5, Section 5) is enriched in biogenic silica and the pore water $\mathrm{SiO}_{2}$ is correspondingly high, but decreases to values less than $100 \mu \mathrm{m}$ in the altered volcanics. This silica-rich sample also produces a very high dissolved $\mathrm{Mn}$ value ( $\sim 8$ $\mathrm{ppm})$, and may reflect an accumulation of ferromanganese oxides during a period of lowered sedimentation rates. The dissolved potassium values are scattered and fairly high, but do not appear to correlate with any mineralogic changes. The dissolved sulfate values are unusually high and $\mathrm{Ca}$ concentrations are 3 to 4 times higher than seawater. Gypsum was detected in Core 7, Section 2 and approximate solubility calculations indicate saturation with respect to this phase. All of the pore water gradients exhibit a marked break in slope across the unconformity between the "Glacial" and underlying Eocene sediments.

\section{Site 344}

This site was drilled on the Knipovich Ridge $15 \mathrm{~km}$ east of the axial rift and the entire section appears to be glacial marine. The glacial sediments have a low and constant amount of heterogeneous illite/smectite, but the illite/smectites increase in the Pliocene and decrease again in the underlying early Pliocene or Miocene(?) sediments.

The basalt at this site is extensively altered and this alteration probably dominates the trends in pore water $\mathrm{Ca}, \mathrm{Sr}, \mathrm{Mg}, \mathrm{Mn}$, and alkalinity (except for sulfate reduction). The gradient in pore water $\mathrm{K}$ reverses (reaching its lowest values) through the smectite-rich Pliocene section. The alteration of the sedimentary volcanics apparently removes $\mathrm{K}$ from the pore waters.

\section{Site 345}

This site was drilled in the Lofoten Basin near the eastern flank of the Mohns Ridge. "Glacial" sediments extend to a depth of 36 meters, and are followed by a Miocene (36-122 m) and a thick Oligocene section. The Miocene and Oligocene sediments are enriched in illite/smectite relative to the "Glacial" sediments indicating a larger altered volcanic contribution.

Again the trends in the pore water gradients of $\mathrm{Ca}$, $\mathrm{Sr}, \mathrm{Mg}$, and alkalinity are probably controlled by the alteration of both the basement basalts and the volcanic 
components of the overlying Oligocene sediments. The values of the pore water $\mathrm{K}$ concentrations are scattered, but correlate with the abundance of illite/smectite. Samples with the higher amounts of smectite presumably reflect a larger amount of altered volcanics which remove $\mathrm{K}$ from the pore waters. The dissolved $\mathrm{SiO}_{2}$ values are highest in the Miocene sediments due to biogenic silica and assume low and constant values within the altered volcanics. Once again the highest $\mathrm{Mn}$ values occur within the siliceous sediments.

\section{Site 348}

This site was drilled on the Icelandic Plateau between the Jan-Mayen Ridge and the Iceland-Jan Mayen Ridge axis. Pleistocene sediments extend to a depth of 75 meters, Pliocene to middle Miocene, 75-256 meters, and lower/middle Miocene to Oligocene, 256 meters to basement. The changes in mineralogy do not strictly corre-

spond to these same age units. The sediments sampled from 6 to 80 meters are presumably glacial and contain low amounts of illite/smectite, while the sediments from 116 to 235 meters have slightly more, but very heterogeneous, illite/smectite. The deepest sediments have a variable illite/smectite content, but the illite/smectites have a higher proportion of smectite layers and are much less heterogeneous. There is a general increase in the detrital clays deeper in this lower section.

The lower section of the Miocene sediments appears to have a larger volcanic contribution. It may have been deposited when the earlier spreading axis was located on the Icelandic Plateau as the Jan Mayen Ridge was separating from Greenland. The oldest sediments in this section contain more detrital clays due to the closer proximity of continental material during the initial spreading. The spreading axis shifted to the present Iceland-Jan Mayen Ridge axis during the middle or late Miocene, and the younger sediments at this site contain a smaller volcanic contribution.

The deepest sediment sample examined (Core 32, Section 2) is approximately 1.3 meters above the basalt and contains euhedral analcime crystals. It appears that the analcime may have formed authigenically within the sediments, but we cannot be certain that it was not reworked from the underlying basalts and thus may have formed under its usual higher temperatures regime (Miyashiro et al., 1971).

The most striking aspect of the pore water gradients is the large depletion in $\delta \mathrm{O}^{18}(-8.3 \%)$. This extreme depletion indicates the extensive involvement of the alteration of the basement basalts in controlling the pore water chemistry (Lawrence et al., 1975). The alteration of the lower Miocene sedimentary volcanics to smectite also appears to be a contributing factor because the marked breaks in the alkalinity and $\mathrm{SiO}_{2}$ gradients correspond to the changes observed in the clay mineralogy. The dissolved $\mathrm{Mg}$ and $\mathrm{K}$ values also become quite low in this lower sediment section.

\section{SUMMARY}

Changes in sediment mineralogy appear to be well correlated with glacial and tectonic events in the Norwegian-Greenland Sea. The abundance of illite/smectite appears to be mainly related to the abundance of volcanic components in the sediments. The alteration of the volcanics and underlying basalts releases $\mathrm{Ca}$ and $\mathrm{Sr}$ to the pore waters and the formation smectite retains the volcanic $\mathrm{Mg}$ and removes additional pore water $\mathrm{Mg}$. The alteration of volcanics also removes pore water $\mathrm{K}$, and the $\mathrm{K}$ concentration levels vary with illite/smectite abundance. Dissolved $\mathrm{SiO}_{2}$ and alkalinity assume low and fairly constant values within the sediment sections enriched in altered volcanics, but the nature of this "buffering" mechanism remains unclear. With the exception of Site 336, zeolites, especially clinoptilolite, are noticeably lacking in the sediments with obvious volcanic contributions. The reason for this also remains unclear, but may possibly be related to higher detrital clay concentrations relative to other sites which we have examined in the Pacific and Indian oceans.

\section{ACKNOWLEDGMENTS}

This research was supported by the Oceanography Section, National Science Foundation (NSF Grant OCE73-00230 A02) and the Petroleum Research Fund administered by the American Chemical Society (PRF 8620-AC2-C).

\section{REFERENCES}

Biscaye, P.E., 1965. Mineralogy and sedimentation of recent deep-sea clay in the Atlantic Ocean and adjacent seas and oceans: Geol. Soc. Am. Bull., v. 76, p. 803-832.

Lawrence, J.R., Gieskes, J.M., and Broecker, W.S., 1975. Oxygen isotope and cation composition of DSDP pore waters and the alteration of layer II basalts: Earth Planet. Sci. Lett., v. 27, p. 1-10.

Miyashiro, A., Shido, F., and Ewing, M., 1971. Metamorphism in the Mid-Atlantic Ridge near $24^{\circ}$ and $30^{\circ} \mathrm{N}$ : Phil. Trans. Roy. Soc. London, Ser. A., v. 268, p. 589-603.

Perry, E.A., Jr., Gieskes, J.M., and Lawrence, J.R., in press. $\mathrm{Mg}, \mathrm{Ca}$ and $\mathrm{O}^{18} / \mathrm{O}^{16}$ exchange in the sediment-pore water system, Hole 149, DSDP: Geochim. Cosmochim. Acta.

Reynolds, R.C. and Hower, J., 1970. The nature of interlayering in mixed-layer illite/montmorillonites: Clays Clay Min., v. 18, p. 25-36. 